УДК $2: 242+141.333+101.8$

\title{
On the Correlation Between the Concepts of Sin, Seduction, Temptation and Charm in Orthodox Anthropology
}

\author{
Elena V. Melnikova* \\ Ural Federal University named after the B. N. Yeltsin \\ 51 Lenin, Ekaterinburg, 620083, Russia
}

Received 22.01.2015, received in revised form 16.02.2015, accepted 19.03.2015

The article attempts to carry out the philosophical reflection of anthropological theological perspective, placing the question of correlation of religious categories on a fundamentally different level, which exceeds the scope of the religious content.

The notions of temptation, seduction and charm are compared. The designated categories are considered as the graduation of the same state, taken in development stages: from ethical neutrality, emotional non-involvement, expressed in the category of "temptation" through the emotional preparedness to respond to external stimuli, which is a test of the moral qualities of the person ("seduction") to willingness to substitute the essence of good - sin ("charm").

Keywords: religion, religious studies, God, temptation, seduction, charm, sin, intention, soul, morals, ethics, penance, theology.

Research area: philosophy.

In the era of postmodernism and postsecularism the interaction of religious and non-religious of conceptual fields is particularly important. Thosecategories thathavetraditionally been used only in the framework of theology and, moreover, under the pressure of scientistic and atheistic attitudes, were expelled from other areas, acquire vernacular meaning today. Even in the legal field the concept of "the believers' feelings" has acquired the specific content. Thus, the anthropological problem of theology merges with the philosophical reflection about the traditional theological categories used for the consideration of the human nature (freedom of spirit, self-determination in the face of God, etc.) and to clarify the issue of the relationship between different aspects of the "body" and "soul" in their modern sense. (Stepanova)

Although the problem of man has been given an important place in theological thought, the special, deep and complete treatment of this topic is relatively new. History of the formation of anthropological foundations is conventionally divided into the ante-Nicene anthropology, anthropology of the great doctrinal disputes, desert, mystics, theological syntheses and Hesychastic (Palamite) ... Only with the XIX century in Western theology

(C) Siberian Federal University. All rights reserved

* Corresponding author E-mail address: e.v.melnikova@urfu.ru 
the phrase "theological anthropology" begins to denote the systematic doctrine of man, to answer the fundamental question: "What is man?" The so-called anthropological turn in theology was driven by the need to be updated to new philosophical tools, which would take into account the recent development of scientific and philosophical thought.

But in fact anthropology as the study of man has never been the subject of a special dogmatic development. The fact is, anthropology in the narrow sense of the word is anthropocentric, which is heresy to Christianity. Therefore, theological anthropology can be defined as a conscious human intention to comprehend himself, his nature, to understand himself as a person through Revelation.

From a Christian perspective, man is the creation of God, but unlike other creatures, he holds a special exclusive place in the hierarchy of the world creation. According to God's plan, he is endowed with special gifts and abilities, which is defined as the image and likeness of God. Man has free will. In the doctrine of man the topic of freedom has a special place. Freedom is eternal, it is given by God to man and man is not free to adopt his freedom, he is an ontologically free creature. Sin is a consequence of freedom, but this does not mean that freedom is the ability to commit sin and that only a sinned man can realize true freedom. The contradictory unity of negative and positive moments is found in freedom. «Negative freedom is the interruption of relations that entangle and constrain and "the way out" is the freedom from restrictions, covenants, laws, regulations, etc. Positive freedom, on the other hand, is the ability to be incorporated into the existing connection and create the conditions in the inner «perceived necessity». The human spirit, on the one hand, strives for freedom beyond the permissible limits and sins, thereby destroying the prevailing unity of spirit, soul and flesh, but on the other hand, is running away from freedom, feeling guilty for his sin and repents, trying a new way to harmonize his unity with the soul and the flesh. Thus, human integrity always has a dynamic equilibriumnonequilibrium nature and is destroyed and built again». (Pivovarov, 275).

Sin (seduction, temptation, charm) can be regarded as an act, reality, fact, or phenomenon of spiritual life. Such understanding of $\sin$ is widespread and is reflected in everyday speech, in textbooks on ethics and moral theology. Sin in this case is a crime of moral norms of law or lawlessness. With this understanding of sin it is inevitable that such questions arise: can any violation of the law be considered a sin? And can we identify something unchanging, eternal, unconditional and something transient, conditional in a sinful deed?

Another approach in the perception of sin does not focus so much on the factual side, the manifestation of sin, a sinful deed, but rather on the internal state of the soul. The original sin of Adam and Eve proved disastrous for the entire human race. The human nature became corrupted, ill, lost its physical and spiritual dignity. Moreover, not only people are sinful but also the world where the evil has entered. The world has lost its former integrity, has become split, interrupted, arhythmical. In the eastern asceticism and liturgy it is common to view sin as a disease of the soul, breaching the pristine harmony of Creation and the divine plan of the world. Sin in this case is an illness, the darkness of the soul. (Kiprian, 405)

The emphasis is thus transferred to the cause of sin, analysis of the internal dialectics, genetic relationship; the soil from which sinful deeds grow so easily is studied, as well as isolated cases of $\sin$.

In Christianity, unlike Judaism and Eastern religions, these concepts are fundamental, because the Christian religion is based on the belief that 
the Son of God, with His sacrificial death atoned for the sins of the people and thereby lead them to the possibility of salvation. Sin is understood here as a direct consequence of freedom, as something that marks the imperfections of the human nature, but at the same time encourages him to achieve repentance, purification and, ultimately, «deification». V.N. Lossky wrote, «what lies within us according to God, is drawn into the abyss, being at the same time free to choose, free to turn again to God.» (Lossky, p. 177). Such action should not be carried out as part of our nature "fallen" and exhausted by sin, but rather in union with Christ: "The human sin immersed the creation into death and destruction, but the restoration of a man in Christ is the restoration of the cosmos into its original beauty." (Meyendorff, p. 217). This is the essence of the Christian worldview.

The seduction is usually defined as a spiritual temptation, as an excuse to sin. "In Greek, the word temptation corresponds to $\sigma \kappa \alpha ́ v \delta \alpha \lambda o v$, i.e. "a peg that supports the trap door". More abstractly, it also means «push», «blow». At the heart of the concept of seduction is the concept of an obstacle on the path which confuses, stops, or leads to a fall (Nravstvennoe bogoslovie, p. 315). With this analogy in mind, we understand the temptation as a circumstance, be it a thought, a feeling, an emotional state, that captivates imagination, confuses, discourages and inclines to sin. In Russian theological literature the word «prilog» is often synonymous with temptation. XV century devotee Nilus of Sora wrote: «Saint Fathers (John of the Ladder, Filofei Sinai and others) identified prilog as a simple thought of any imagined object, which suddenly appears in the heart and mind. St. Gregory of Sinai says, «Prilog is a suggestion, coming from the enemy: do this or that, as with Christ Himself, our God: command that these stones be made bread (Matt. 4:3).» (Sorsky, p. 14)
Also, Reverend Mark the Ascetic (IV c.) says: «Prilog (thought) is an involuntary movement of the heart, not accompanied by images. It opens, like a key, the door to sin in the heart, which is why the experienced try to drive it away in the beginning.» (Mark the Ascetic, p. 21)

Interestingly, according to Nilus Sora, prilog is ethically neutral. Man, whose consciousness is penetrated by temptation, is usually not guilty. Prilog is called "sinless; it deserves neither praise nor condemnation, because it does not depend on us. For it is impossible to avoid temptations from the enemy." (Sorsky, p. 15). The temptation is exactly like this. It occurs without the participation of the mind and the heart, as it comes from the outside; it does not subdue, but already confuses a man.

The temptation, from a Christian view point, is a consequence of weakness. It is a thought capable of making (but in the case of temptation not forcing) us to submit to some external impulse. As such, the temptation may be a precursor to sin. It is stated in one of Christ's evangelical preachings: "If thy right eye offend thee, pluck it out and cast it from thee: for it is for you to lose one of your members, and not that thy whole body should be cast into hell. And if thy right hand offend thee, cut it off and cast it from thee: for it is for you to lose one of your members, and not that thy whole body should be cast into hell "(Matt.: 5, 22-23).

Another meaning of temptation is a mistake, which distorts the essence of some phenomenon. For example, you can be tempted when interpreting a text, assessing events, understanding the limits of a human and superhuman (divine). The last idea was meant when the Savior said: "And blessed is he who is not tempted by Me" (Matt.: 11, 6).

The worst form of temptation is making others lie or commit sins; those who get seduced through ignorance or trust. According to St. John Chrysostom, "it is not as detrimental to 
sin yourself as to make others sin.’(Chrysostom, p. 41).

Temptation is a concept akin to the seduction (though perhaps more complex) and just as often used in moral theology. According to one of the classic definitions, temptation is "test, which reveals the true properties of the human soul good or bad.'(Polnyi prav. bogosl. entsikl. slovar', p. 486). If we specify this definition, we can say that the temptation is a test of being seduced. In Nilus of Sora's terminology temptation is a "combination", following the prilog itself; it is an "interview (soglagolati) with the conceived thought - passionate or dispassionate - or acceptance of the idea coming from the enemy, its retention, consent with it and arbitrary admission of it to be within us. And even the Holy Fathers do not accept it as sinless.”(Sorsky, p. 16) In other words, if the temptation is a thought that, in principle, could serve as an obstacle to good life, but has not yet become such, then the temptation is the interest in these thoughts, the direction of mind and will on its implementation.

Another difference between temptation and seduction is that if the temptation is often a thought (or thoughts), the seduction always encompasses the area of feelings. Temptation is experiencing seduction. It is not accidentally that St. Isaac the Syrian speaks about the temptation in exactly that chapter of his "Words on asceticism ", which is devoted to the analysis of the senses and sensuality. Isaac believes that the source of temptation may be a simple interest in things: “... when the soul does not accept a sense of things, then victory is accomplished without a fight. If a man neglects and allows to succumb to temptations, he is then forced to endure abuse." (Syrus, 39). "Temptations" emanating from the things (the outside world in general) tend to be harmful to the soul. However, there are such temptations that, according to Isaac the Syrian, every believer must experience: "Do not give up your sorrows, because they lead you into the knowledge of the truth, and do not be afraid of temptations because through them you gain verity." (Syrus, 44). Temptations are needed as trials in which the soul of a Christian is tempered and strengthened: "For outside temptation the Providence of God is not seen, it is impossible to acquire boldness before God, it is impossible to learn the wisdom of the Spirit, there is also no possibility that God's love will establish itself in your soul." (Syrus, 47). Here temptation is perceived as a way to "purify" the suffering, and, apparently, Rev. Isaac does not believe that we should strictly avoid them. F.M. Dostoevsky can be considered one of the followers of such an interpretation of temptation.

In the works of some religious thinkers the concept of temptation often acquires a high religious meaning, denoting the desire to expand the boundaries of human existence to the extent of exceeding human measure. For example, a Russian theologian M.M. Tareev distinguished between "moral" temptation and "religious" temptation. About the latter he wrote: "...The religious consciousness of an individual, if it stands with its intensity above the general level of everyday interests, must pass through the temptation of the natural limitations of nature." (Tareev, 132). Religious temptation is a "temptation by natural weaknesses" of human nature, reflecting the desire of man to reveal a different nature - the divinehuman. They "are created by the contradiction between the limited and the ideal that is granted to a person or the dignity in which he himself is aware of." (Tareev, 133). In religious temptations, as Tareev says, there is a God-fighting element, but it is soon overcome by humility and love, found through faith.

Let us consider another concept of moral theology, closely related to notions of seduction and temptation. This is "seduction" or "charm". In terms of the above-mentioned teachings of St. 
Nilus of Sora charm is a "captivity". "Captivity is, says Neal, when the heart against its will rushes to the found thoughts and dwell in it and falls from its spiritual mood." (Sorsky, 18). Thus, if the seduction is a thought coming from the outside, then the temptation is a felt seduction; thus we can define charm as a temptation, which internally (in the mind and heart) "captivates" a person.

According to theologians, in this case, imaginary good is always perceived as the true good, i.e., lie is perceived as truth. Therefore, there is always a tinge of self-deception and delusion in the concept of charm. Let us compare St. Ignatius Brianchaninov's definition: "Charm is the damage to human nature through lies." (Bryanchaninov). The same St. Ignatius says: "All of us are immersed in charm. Knowing this is the greatest protection against charm. The greatest charm is to recognize oneself free from the charm." (Bryanchaninov). Man falls into the charm at the moment when he begins to think that in life there is some immanent truth (or truths), while forgetting that the truth is only one, and it is God. Therefore, all of us, in one way or another, consciously or unconsciously, are prisoners of charm.

But this aspect of this concept (let us call it ontological) does not exhaust the entire depth of its meaning. What St. Ignatius meant by the "charm" is substantially comparable to the original sin. It is not by chance that he says, that it is since the fall of the first people "our nature, infected by poison of evil, aspires voluntarily and unwittingly to the evil, which presents itself as the good and charm by the distorted will, perverted mind, perverted sensation of heart." (Bryanchaninov). However, the charm is also related to the particular situation (delusion), which a man experiences not only in the universal "subtext" in other situations, but with them. According to St. Theophan the Recluse, "there is a mental charm, which is a conceit; there is external one - it's light, sound, some shapes." (Theophan). A man can be charmed by a particular charm, if pride is strong in him (the beginning of "self-conceit") and a penchant for sensual pleasures (the latter - not necessarily the carnal ones; Christian theologians often put other pleasures, such as aesthetic in that category).

Thus, temptation, seduction and charm are all gradations of the same state: the penetration of the external into the mind and heart of man, that is what is not related to the true good intention.

"Temptation" is an ethically neutral category, in the sense that the person has not yet accepted the idea of temptation; he is able to give it up without being emotionally involved. "Seduction» is a kind of trial of a person's moral qualities emotionally prepared to accept any rejection of sin. "Charm" is a category indicating that the person could not resist the temptation; he is willing to realize his aspiration for sin, he desires it, often taking sin for good.

All of the above categories can be understood as three stages on the path to sin. From the view point of Orthodox theology, there is only one way to deal with them - prayer and repentance. According to Reverend Nilus Sora, "we defeat them with perpetual repentance and unceasing prayer and we will not give our shoulders (our back) to our enemies, that is, let us not go backwards, although every day we received thousands of wounds from them."'( Sorsky, 23).

Thus, the texts of theological philosophizing provide us with rich religious human experience, which is important not only for «living in Christ», but also for anyone, because it has a universal human meaning.

The study of the genesis of the ethical and psychological state of an individual, described so carefully in the Orthodox Christianity, will reveal the fundamental humanitarian stratum of the spiritual heritage, which is the basis of the Russian identity. We hope that this approach will 
avoid the extremes in all those areas (education and teaching, intercultural and inter-ethnic dialogue, etc.), where the secular and religious views on morality and ethics interact. In this way we have to abandon classification of certain concepts and categories exclusively to the realm of theology, having recognized their universal human sense.

The carried out analysis of categories makes it possible to continue exploring the anthropological perspective in other aspects epistemological, ethical and praxeological.

\section{References}

1. Bryanchaninov Ignatius, St. O prelesti [About charm]. Available at: http://apologet.spb.ru/ $\mathrm{ru} / 1189 . \mathrm{html}$ (accessed 2 february 2015)

2. Chrysostom John, St. Nastavlenia v khristianskoi zhizni [Teachings of the Christian life]. Moskow, 2012. 48 p.

3. Kiprian, the right rev. Antropologiya Sv. Grigoriya Palamy. [Anthropology of St. Gregory Palamas]. Kiyv, 2006. 436 p.

4. Lossky V.N., Oherk misticheskogo bogosloviia Vostochnoi tserkvi [Essay on mystical theology of the Eastern Church]. Misticheskaia Teologiia [Mystical Theology]. Kiev, 1991, pp. 95-260.

5. Mark the Ascetic, Rev. Prostranstvo serdtsa [Space of heart]. Moskow, 2008. $60 \mathrm{p}$.

6. Meyendorff John, the Very Rev., Vizantiiskoe bogoslovie [Byzantine theology]. Minsk, 2007. $338 \mathrm{p}$.

7. Nravstvennoe bogoslovie: slovar' naibolee upotrebitel'nykh terminov [Moral theology: a dictionary of the most common terms]. Saint-Petersburg., 2010. $450 \mathrm{p}$.

8. Pivovarov D.V. Philosophiya religii [Philosophy of Religion]. In 3 v. V. 1 Yekaterinburg: Publishing House of Ural University.2011. 390 p.

9. Polnyi pravoslavnyi bogoslovskii entsiklopedicheskii slovar' [Complete Orthodox Theological Encyclopedic Dictionary]. V. 1. Moskow., 1912. 560 p. 486

10. Sorsky Nil. O vos'mi glavnykh strastiakh I pobede nad nimi [About eight main passions and victory over them]. Moskow, 2009. 62 p.

11. Syrus Isaac, St. Word on asceticism. Moscow, 2006. p. 39

12. Stepanova E.A. Teologicheskaya antropologiya: traditsiya I sovremennost' [Theological Anthropology: tradition and modernity]. Nauchnyi iezhegodnik Instituta filosofii i prava Ural'skogo otdeleniya rossiiskoi akademii nauk [Year-Book of Institute of philosophy and law of Ural branch of The russian academy of sciences]. Yekaterinburg, 2004, 5, pp. 148-167.

13. Tareev M.M. Iskusheniia gospoda nashego Iisusa Khrista. [he temptation of our Lord Jesus Christ]. Moscow, 1900. 200 p. 132

14. Theophan the Recluse, St. Sozertsanie i razmyshlenie [Contemplation and thoughts]. Available at: http://www.paraklit.org/sv.otcy/Feofan_Zatvornik/Feofan_Zatvornik.Sozertcanieirazmishlenie. htm (accessed 2 february 2015)/ 


\title{
О соотношении понятий «грех», «соблазн», «искушение»
}

\section{и «прелесть» в православной антропологии}

\author{
Е.В. Мельникова
}

Уральский федеральный университет им. Б.Н. Ельцина, Россия 620083, Екатеринбург, пр. Ленина, 51

В статье предпринята попытка философской рефлексии антропологической богословской проблематики, выводящей вопрос соотношения религиозных категорий на принципиально иной, превосходящий рамки религиозного содержания, уровень. Сопоставляются понятия «грех», «соблазн», «искушение» и «прелесть». Обозначенные категории рассматриваются как градации одного и того же состояния, взятые в развитии, поэтапно: от этической нейтральности, эмоциональной невовлеченности, выражающейся в категории «соблазн», через эмоциональную подготовленность к реакции на внешние воздействия, являюшуюся проверкой нравственных качеств человека («искушение»), к готовности подмены сущности блага - греха («прелесть»).

Ключевые слова: религия, религиоведение, антропология, Бог, соблазн, искушение, прелесть, грех, помысел, душа, нравственность, этика, покаяние, богословие.

Научная специальность: 09.00.00 - философские науки. 